\title{
Review of the relationship between milk urea nitrogen and days in milk, parity, and monthly temperature mean in Iranian Holstein cows
}

\author{
F. Fatehi, ${ }^{\star 1}$ A. Zali, ${ }^{*}$ M. Honarvar,† M. Dehghan-banadaky, ${ }^{\star}$ A. J. Young,‡ M. Ghiasvand, ${ }^{*}$ and M. Eftekhari \\ *Department of Animal Science, Campus of Agriculture and Natural Resources, University of Tehran, Karaj, Tehran, Iran 31587-77871 \\ †Department of Animal Science, Shahr-e-Qods Branch, Islamic Azad University, Tehran, Iran 37515-374 \\ ‡Department of Animal, Dairy, and Veterinary Sciences, Utah State University, Logan 84322
}

\section{ABSTRACT}

The objectives of this study were to determine the relationships between milk urea $\mathrm{N}$ and days in milk, parity, and season in Iranian Holstein cows. Twelve Iranian commercial dairy herds participated in a 13-mo study from December 1, 2008, to December 31, 2009. All cows were milked 3 times daily, housed in freestalls, and fed a total mixed ration twice a day. Mean milk urea $\mathrm{N}$ over the study period was $16.0 \mathrm{mg} / \mathrm{dL}$. Mean milk urea $\mathrm{N}$, categorized by $30-\mathrm{d}$ increments of days in milk, paralleled changes in milk values and followed a curvilinear shape. However, milk urea $\mathrm{N}$ concentration reached a maximum at the fifth month of days in milk, but milk production reached a maximum at the third month. The concentration of milk urea $\mathrm{N}$ was lower during the first $30 \mathrm{~d}$ in milk category compared with all other days in milk categories. Overall mean milk urea $\mathrm{N}$ concentration of Holstein cows in the third and greater lactations was lower than in the first or second lactation. Milk urea $\mathrm{N}$ was at its lowest level in December $(13 \mathrm{mg} / \mathrm{dL})$, increased in the spring and summer months, and reached a maximum in July (18.8 $\mathrm{mg} / \mathrm{dL}$ ). From that point, milk urea $\mathrm{N}$ concentration progressively diminished to the autumn-winter level. In this study, milk urea $\mathrm{N}$ concentration was positively correlated with monthly temperature mean and may be a reason for the lower reproductive performance during the summer months. It has been recommended that milk urea $\mathrm{N}$ concentration should be evaluated in association with parity, days in milk, and season (or month). These variables should be considered potential sources of misinterpretation when exploring the relationship between milk urea $\mathrm{N}$ and nutritional management or measures of performance.

Key words: Iranian Holstein cow society, milk urea nitrogen, parity, season

Received March 8, 2011.

Accepted April 9, 2012.

${ }^{1}$ Corresponding author: fatehif@ut.ac.ir

\section{INTRODUCTION}

Considerable interest has developed in using MUN as a monitor of the efficiency of $\mathrm{N}$ utilization by dairy cows (Baker and Ferguson, 1993). The amount of urea a cow excretes in the urine is directly proportional to the concentration of urea in the blood, and this amount is proportional to the concentration of urea in the milk (Gustafsson and Palmquist, 1993). Therefore, MUN should be a good predictor of urinary $\mathrm{N}$ excretion by dairy cows (Wood, 1979; Gustafsson and Palmquist, 1993; Kohn et al., 2002) and a way to monitor the efficiency of protein utilization in dairy herds.

Blood urea $\mathrm{N}$ is the major end product of $\mathrm{N}$ metabolism in ruminants, and high concentrations of BUN are indicative of excess dietary $\mathrm{N}$ or RDP. However, BUN is difficult to measure routinely owing to the problem of obtaining regular and reliable samples. It is well established that urea equilibrates rapidly with body fluids, including milk, and this can account for the close relationship between MUN and BUN (Broderick and Clayton, 1997; Hof et al., 1997). Because milk is easily collected and urea can be determined accurately by enzymatic or physical methods, it has often been suggested that MUN could be used as a diagnostic of on-farm efficiency of N utilization (Jonker et al., 1998; Kauffman and St-Pierre, 2001; Kohn et al., 2002).

Evidence exists that MUN can be affected not only by nutritional factors, such as dietary $\mathrm{CP}$ content, the ratio of dietary $\mathrm{CP}$ to energy, the extent of $\mathrm{CP}$ degradation in the rumen, the amount of $\mathrm{NH}_{3}$ in excess of microbial $\mathrm{N}$ requirements, and protein or energy intake in relation to feeding standards (Carlsson et al., 1995; Hof et al., 1997), but also by other nonnutritional factors, such as DIM, parity, and season.

One additional concern regarding the overfeeding of protein to dairy cows is the potential impairment of reproduction, because urea, $\mathrm{NH}_{3}$, or other nitrogenous compounds may create a hostile environment in reproductive tissues that prevents pregnancy (Swenson and Reece 1993; Ferguson et al., 1997; Kohn et al., 2002). As a result, Jordan and Swanson (1979) observed that ova and sperm viability was reduced when dietary pro- 
tein was excessive. Dairy cows with high blood urea concentrations have been reported to have reduced conception rates (Ferguson et al., 1997; Jonker et al., 1998). Overfeeding also contributes to higher feed costs (Kaim et al., 1983; Ferguson et al., 1988; Blanchard et al., 1990; Baker et al., 1995). Conversely, underfeeding protein may result in impaired fertility (Miettinen and Juvonen, 1990) and suboptimal milk production (Baker et al., 1995).

The association between MUN and both nutritional management and performance should be determined under field conditions by using commercial testing procedures (Bonnett, 1990; Sackett et al., 1991). To investigate these associations, a measure of the nonnutritional factors affecting MUN is needed. The objectives of this study were to determine the relationships between MUN and DIM, parity, and season in Iranian Holstein cows.

\section{MATERIALS AND METHODS}

\section{Data Collection}

Twelve Iranian commercial dairy herds participated in a 13-mo study from December 1, 2008, to December 31, 2009. All cows were milked 3 times daily, housed in freestalls, and fed a TMR twice a day, but no classification was made for management style and feeding scheme. Test data included date, herd number, cow number, and individual cow information (parity, breeding dates, and milk yield). Milk samples were analyzed for MUN (mg/dL) using an automated IR Fossomatic 4000 Milk Analyzer (Foss North America, Brampton, ON, Canada). Data were obtained electronically from the milk improvement center laboratory after each test day and stored in a database by herd, cow, and testday identification (Microsoft FoxPro, Version 2.6 for Windows, Microsoft Corporation, Redmond, WA).

Missing values were coded as such in the database, and each production variable was screened for outliers. Milk urea $\mathrm{N}$ concentrations $<1$ or $>40 \mathrm{mg} / \mathrm{dL}$ were excluded from the analysis as outliers. Cows with milk production $>84 \mathrm{~kg}$ were also excluded.

\section{Statistical Analyses}

Descriptive Statistics. Descriptive statistics were computed for DIM, milk yield, MUN, milk protein and fat percentages, and parity by using the PROC FREQ procedure of SAS (SAS Institute, 2004). Simple correlation coefficients and principal component analyses were calculated to determine collinearity (SAS Institute, 2004). Variables correlated at $\mathrm{r}>0.5$ were not included in the same model (e.g., season and month). Least squares means were determined for MUN concentration and milk yield by DIM categories using the PROC MIXED procedure in SAS (SAS Institute, 2004). Parity, DIM, and test month within test year were added to the model as covariates. Cow within herd was included in the random statement to control for repeated measures within herd on different test days.

Categories. Days in milk were grouped into 30-d increments, with those greater than $360 \mathrm{~d}$ grouped into one category. Cows were grouped by lactation number into first, second, and third and greater. Milk production was grouped by increments of $9.1 \mathrm{~kg} / \mathrm{d}(20 \mathrm{lb} / \mathrm{d})$, with the upper grouping of $\geq 63.6 \mathrm{~kg}$ for Holstein cows. Milk protein percentage categories were similar to those of Johnson and Young (2003), with categories $\leq 3.01$, 3.01 to 3.2 , and $>3.2 \%$ milk protein.

Associations Between MUN Concentrations and DIM and Parity. Multivariate mixed linear regression models using the PROC MIXED procedure in SAS (SAS Institute, 2004) were used to determine the association between MUN (dependent variable) and DIM and parity categories (independent variables). Test month within test year was added to the model as a covariate. Multiple comparisons were made with $P$-values adjusted using Tukey's procedure. Cow within herd was added to the random statement to control for repeated measures within herd on different test days.

Associations Between MUN Categories and Production Variables. Multivariate linear regression (PROC MIXED in SAS) was used to determine the associations between milk yield, milk fat, protein, SNF, and TS percentages (dependent variables) and MUN categories (independent variable). Parity, DIM, and month of test within year of test were added to the model as covariates. Reported values are true protein. Least squares means were determined for Iranian Holstein cows. Cow within herd was included in the random statement to control for repeated measures within herd on different test days.

Associations Between MUN and Combinations of Milk Yield and Milk Protein Percentage Categories. Multivariate linear regression (PROC MIXED in SAS) was used to determine the association between MUN (dependent variable) and milk yield and protein categories (independent variables; Nelson, 1996). Parity, DIM, and test month within test year were added to the model as covariates. Cow within herd was added to the random statement to control for repeated measures within a herd on different test days. Multiple comparisons were made, with $P$-values adjusted using Tukey's procedure.

Associations Between MUN Concentrations and Season (or Month). Multivariate mixed linear regression (PROC MIXED in SAS) was used to 
Table 1. Least squares means and SD of DHI variables for Iranian Holstein cows

\begin{tabular}{lrrcc}
\hline Variable & LSM & \multicolumn{1}{c}{ SD } & Minimum & Maximum \\
\hline DIM & 186.7 & 126.72 & 10 & 420 \\
Milk, kg/d & 30.0 & 10.46 & 5 & 77.8 \\
MUN, mg/dL & 16.0 & 4.99 & 4.9 & 36.5 \\
Protein,\% & 3.12 & 0.40 & 2.4 & 5.1 \\
Fat, \% & 3.42 & 1.06 & 2.2 & 6.3 \\
Lactose, \% & 4.51 & 0.36 & 3.7 & 5.1 \\
TS, \% & 11.79 & 1.70 & 9.7 & 13.4 \\
SNF, \% & 9.02 & 1.11 & 7.6 & 11.8 \\
Parity & 2.66 & 1.86 & 1 & 6 \\
\hline
\end{tabular}

determine the relationship between MUN (dependent variable) and month or season (March to May; June to August; September to November; December to February) as independent variables. Because the variables season and month were highly correlated, they were not included together in the final multivariate model. A likelihood ratio test showed that the inclusion of month yielded a better fit than did season.

\section{RESULTS}

\section{Characterization of the Database}

Data set included 12,514, 8,094, and 13,910 records for lactation groups 1,2 , and $\geq 3$, respectively. Descriptive statistics for Iranian Dairy Herd variables are listed in Table 1. Mean DIM for Iranian Holsteins was $187 \mathrm{~d}$ and was higher than reported in other studies (Jonker et al., 1998; Godden et al., 2001a). Average milk yield was $30 \mathrm{~kg}$ and was similar to what has been reported in other MUN studies (Carlsson et al., 1995; Godden et al., 2001a,b). Mean MUN (mg/dL) was 16.0 and average cow-level MUN concentrations were higher than values reported in other studies (Godden et al.,

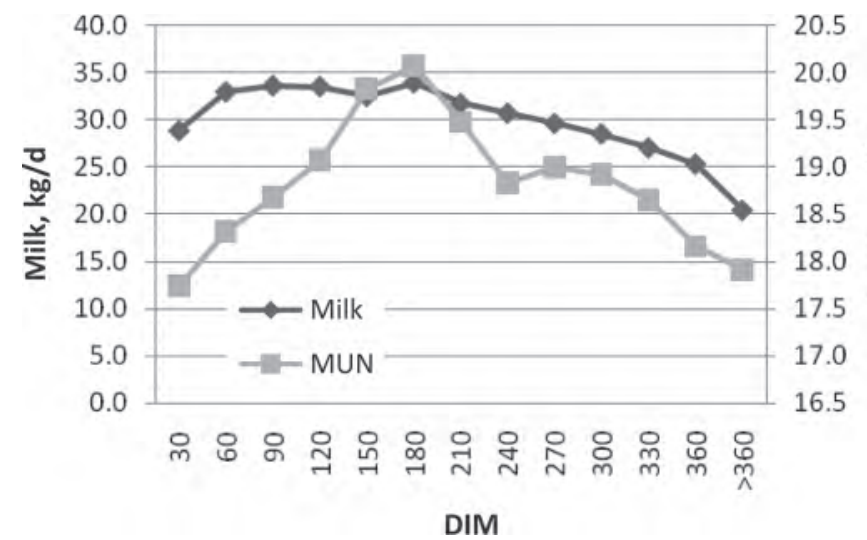

Figure 1. Least squares means of MUN concentration and milk yield by 30-d DIM categories for Iranian Holstein cows.

2001a; Rajala-Schultz et al., 2001; Johnson and Young, 2003). This difference may have been due to different feeds, sources of feeding, and feeding procedures used in the dairy herds in Iran. The mean parity was 2.66 and is similar to the reports of Godden et al. (2001a) and Johnson and Young (2003).

Associations Between MUN and DIM and Between MUN and Parity. Mean milk yield and MUN concentrations, by DIM categories, were curvilinear (Figure 1 and Table 2). Mean MUN concentration, by DIM categories and parity, are shown in Table 2 . The results of this study are consistent with previous studies reporting that MUN varied by stage of lactation (Bruckental et al., 1980; Carlsson et al., 1995). Overall mean MUN concentration of Holstein cows in the third or greater lactation was lower $(P<0.05)$ than those in the first or second lactation (Figure 2).

Associations Between MUN Categories and Production Variables. An inverse relationship was

Table 2. Milk urea N concentration by DIM category and parity for Iranian Holstein cows

\begin{tabular}{|c|c|c|c|c|c|c|c|c|}
\hline \multirow[b]{2}{*}{ DIM category } & \multicolumn{2}{|c|}{ Lactation 1} & \multicolumn{2}{|c|}{ Lactation 2} & \multicolumn{2}{|c|}{ Lactation $3+$} & \multicolumn{2}{|c|}{ All } \\
\hline & $\mathrm{n}$ & Mean & $\mathrm{n}$ & Mean & $\mathrm{n}$ & Mean & $\mathrm{n}$ & Mean \\
\hline$\leq 30$ & 1,248 & $15.76^{\mathrm{a}}$ & 984 & $14.39^{\mathrm{b}}$ & 1,708 & $14.07^{\mathrm{c}}$ & 3,940 & 14.7 \\
\hline$\overline{31}-60$ & 1,018 & $16.46^{\mathrm{a}}$ & 724 & $14.86^{\mathrm{b}}$ & 1,256 & $14.64^{\mathrm{b}}$ & 2,998 & 15.3 \\
\hline $61-90$ & 1,046 & $16.73^{\mathrm{a}}$ & 778 & $15.08^{\mathrm{b}}$ & 1,314 & $15.23^{\mathrm{b}}$ & 3,138 & 15.7 \\
\hline $91-120$ & 946 & $16.26^{\mathrm{a}}$ & 812 & $15.95^{\mathrm{b}}$ & 1,292 & $15.98^{\mathrm{b}}$ & 3,050 & 16.1 \\
\hline $121-150$ & 914 & $17.33^{\mathrm{a}}$ & 668 & $17.61^{\mathrm{b}}$ & 1,162 & $16.08^{\mathrm{c}}$ & 2,744 & 17.0 \\
\hline $151-180$ & 1,084 & $17.28^{\mathrm{a}}$ & 682 & $17.32^{\mathrm{a}}$ & 1,184 & $16.04^{\mathrm{b}}$ & 2,950 & 16.9 \\
\hline $181-210$ & 1,130 & $17.04^{\mathrm{a}}$ & 664 & $16.96^{\mathrm{a}}$ & 1,220 & $15.4^{\mathrm{b}}$ & 3,014 & 16.5 \\
\hline $211-240$ & 1,102 & $16.61^{\mathrm{a}}$ & 598 & $16.41^{\mathrm{b}}$ & 1,054 & $15.06^{\mathrm{c}}$ & 2,754 & 16.0 \\
\hline $241-270$ & 948 & $17.16^{\mathrm{a}}$ & 554 & $15.7^{\mathrm{b}}$ & 990 & $15.12^{\mathrm{c}}$ & 2,492 & 16.0 \\
\hline $271-300$ & 768 & $17.62^{\mathrm{a}}$ & 426 & $15.69^{\mathrm{b}}$ & 784 & $14.46^{\mathrm{c}}$ & 1,978 & 15.9 \\
\hline $300-330$ & 566 & $17.84^{\mathrm{a}}$ & 306 & $14.8^{\mathrm{b}}$ & 586 & $14.42^{\mathrm{b}}$ & 1,458 & 15.7 \\
\hline $331-360$ & 508 & $17.29^{\mathrm{a}}$ & 280 & $14.72^{\mathrm{b}}$ & 468 & $14.01^{\mathrm{b}}$ & 1,256 & 15.3 \\
\hline$\geq 360$ & 1,236 & $16.97^{\mathrm{a}}$ & 618 & $14.41^{\mathrm{b}}$ & 892 & $13.34^{\mathrm{c}}$ & 2,746 & 14.9 \\
\hline Total/average & 12,514 & $16.95^{\mathrm{a}}$ & 8,094 & $15.68^{\mathrm{b}}$ & 13,910 & $14.91^{\mathrm{c}}$ & 34,518 & 16.0 \\
\hline
\end{tabular}

\footnotetext{
${ }^{\mathrm{a}-\mathrm{c}}$ Least squares means within the same row with different superscripts differ $(P<0.05)$.
} 
Table 3. Milk yield, protein, fat, SNF, and TS percentages by MUN concentration category for Iranian Holstein cows

\begin{tabular}{|c|c|c|c|c|c|c|c|c|c|c|c|}
\hline $\begin{array}{l}\text { MUN category, } \\
\mathrm{mg} / \mathrm{dL}\end{array}$ & $\mathrm{n}$ & \multicolumn{2}{|c|}{ Milk } & \multicolumn{2}{|c|}{ Protein, $\%$} & \multicolumn{2}{|c|}{ Fat, $\%$} & \multicolumn{2}{|c|}{ SNF, $\%$} & \multicolumn{2}{|c|}{ TS, $\%$} \\
\hline$\leq 6.0$ & 674 & $25.52^{\mathrm{f}}$ & 0.238 & $3.41^{\mathrm{a}}$ & 0.008 & $3.96^{\mathrm{a}}$ & 0.026 & $9.15^{\mathrm{a}}$ & 0.025 & $12.20^{\mathrm{a}}$ & 0.039 \\
\hline $8.01-10$ & 1,804 & $28.75^{\mathrm{d}}$ & 0.330 & $3.27^{\mathrm{b}}$ & 0.012 & $3.69^{\mathrm{b}}$ & 0.036 & $9.20^{\mathrm{a}}$ & 0.035 & $11.92^{\mathrm{bc}}$ & 0.055 \\
\hline $10.01-12$ & 2,088 & $29.26^{\mathrm{d}}$ & 0.307 & $3.23^{\mathrm{c}}$ & 0.011 & $3.66^{\mathrm{bc}}$ & 0.033 & $9.13^{\mathrm{a}}$ & 0.032 & $11.95^{\mathrm{bc}}$ & 0.051 \\
\hline $12.01-14$ & 3,714 & $30.51^{\mathrm{bc}}$ & 0.282 & $3.19^{\mathrm{d}}$ & 0.010 & $3.59^{\mathrm{cd}}$ & 0.031 & $9.11^{\mathrm{ab}}$ & 0.030 & $11.86^{\mathrm{cd}}$ & 0.047 \\
\hline $18.01-20$ & 2,768 & $31.21^{\mathrm{ab}}$ & 0.272 & $3.15^{\mathrm{fg}}$ & 0.009 & $3.40^{\text {ef }}$ & 0.030 & $9.02^{\mathrm{cd}}$ & 0.029 & $11.75^{\text {de }}$ & 0.045 \\
\hline $20.01-22$ & 2,594 & $31.09^{\mathrm{abc}}$ & 0.280 & $3.14^{\mathrm{fgh}}$ & 0.010 & $3.30^{\mathrm{g}}$ & 0.030 & $8.97^{\mathrm{de}}$ & 0.030 & $11.64^{\mathrm{e}}$ & 0.046 \\
\hline $22.01-24$ & 2,934 & $31.13^{\mathrm{ab}}$ & 0.266 & $3.13^{\mathrm{gh}}$ & 0.009 & $3.34^{\mathrm{f}}$ & 0.029 & $8.90^{\mathrm{e}}$ & 0.028 & $11.66^{\mathrm{e}}$ & 0.044 \\
\hline$>24$ & 6,428 & $31.29^{\mathrm{a}}$ & 0.179 & $3.12^{\mathrm{h}}$ & 0.006 & $3.15^{\mathrm{h}}$ & 0.019 & $8.81^{\mathrm{f}}$ & 0.019 & $11.46^{\mathrm{f}}$ & 0.030 \\
\hline
\end{tabular}

${ }^{\mathrm{a}-\mathrm{h}}$ Least squares means within the same column with different superscripts differ $(P<0.05)$.

observed between MUN categories and milk fat and milk protein percentages in the current study (Table 3 ). As milk fat and milk protein percentages increased, MUN concentration decreased.

Associations Between MUN and Combinations of Milk Yield and Milk Protein Percentage Categories. The concentrations of MUN categorized by milk yield and milk protein categories of $<3.0,3.01$ to 3.2 , and $>3.2 \%$ are shown in Table 4 . Milk urea $\mathrm{N}$ was lower when milk protein was $>3.2 \%$ (vs. $<3.0 \%$ or 3.01 to $3.2 \%$ ). In addition, MUN was lower for cows with 3.01 to $3.2 \%$ milk protein than the group with $>3.2 \%$ milk protein for all milk yield categories. Because of these relationships, milk protein percentage should be considered in addition to MUN concentration as a management tool for determining if rations are properly balanced for production (Johnson and Young, 2003).

Associations Between MUN and Season (or Month). Milk urea N was at its lowest level in December $(13 \mathrm{mg} / \mathrm{dL})$, increased in the spring and summer months, and reached a maximum in July of $18.8 \mathrm{mg} / \mathrm{dL}$ (Table 5 and Figure 3). From that point, MUN concentration progressively diminished to the autumn-winter level.

\section{DISCUSSION}

\section{Associations Between MUN and DIM}

The concentration of MUN was lower during the first 30 DIM category compared with all other DIM categories. Others have shown this same association (Carlsson et al., 1995; Eicher et al., 1999; Godden et al., 2001a). A factor that might reduce MUN in the first month of lactation is the inability of cows to ingest sufficient feed early in lactation, leading to relatively lower protein intake (Carlsson et al., 1995). However, further work to determine the cause of the lower MUN during this time period would be helpful when using MUN concentrations as a management tool.

In this study, MUN increased slowly over the first 4 mo and reached a peak in the fifth month of lactation (Figure 1). These results do not agree with those of Ng-Kwai-Hang et al. (1985), who reported that milk NPN fell rapidly after calving, and then gradually rose through to the end of lactation. Our result was in agreement with the study by Carlsson et al. (1995), who reported that MUN reached a maximum between 3 and 6 mo of lactation and then slowly decreased in later lactation. Johnson and Young (2003) observed

Table 4. Milk urea N concentration by milk yield and protein percentage categories for Iranian Holstein cows

\begin{tabular}{|c|c|c|c|c|c|c|c|c|c|c|c|c|}
\hline \multirow[b]{2}{*}{$\begin{array}{l}\text { Milk } \\
\text { category, kg }\end{array}$} & \multicolumn{3}{|c|}{$\leq 3.01 \%$} & \multicolumn{3}{|c|}{$3.01-3.20 \%$} & \multicolumn{3}{|c|}{$>3.20 \%$} & \multicolumn{3}{|c|}{ All } \\
\hline & $\mathrm{n}$ & $\begin{array}{l}\text { MUN, } \\
\mathrm{mg} / \mathrm{dL}\end{array}$ & SE & $\mathrm{n}$ & $\begin{array}{l}\text { MUN, } \\
\mathrm{mg} / \mathrm{dL}\end{array}$ & SE & $\mathrm{n}$ & $\begin{array}{l}\text { MUN, } \\
\mathrm{mg} / \mathrm{dL}\end{array}$ & SE & $\mathrm{n}$ & Mean & SE \\
\hline $18.21-27.3$ & 1,450 & $17.12^{\mathrm{a}}$ & 0.083 & 2,214 & $15.12^{\mathrm{b}}$ & 0.049 & 3,722 & $14.82^{\mathrm{c}}$ & 0.044 & 7,386 & 15.69 & 0.025 \\
\hline $27.31-36.4$ & 2,878 & $17.49^{\mathrm{a}}$ & 0.044 & 3,772 & $15.57^{\mathrm{b}}$ & 0.049 & 4,172 & $15.17^{\mathrm{c}}$ & 0.027 & 10,822 & 16.08 & 0.049 \\
\hline $36.41-45.5$ & 2,884 & $17.52^{\mathrm{a}}$ & 0.065 & 2,180 & $15.88^{b}$ & 0.043 & 1,884 & $15.37^{\mathrm{c}}$ & 0.039 & 6,948 & 16.26 & 0.059 \\
\hline Total/average & 9,876 & $17.33^{\mathrm{a}}$ & 0.270 & 10,476 & $15.68^{\mathrm{b}}$ & 0.448 & 13,530 & $15.22^{\mathrm{b}}$ & 0.350 & 33,882 & 16.08 & 0.068 \\
\hline
\end{tabular}

\footnotetext{
${ }^{\mathrm{a}-\mathrm{c}}$ Least squares means within the same row with different superscripts differ $(P<0.05)$.
} 


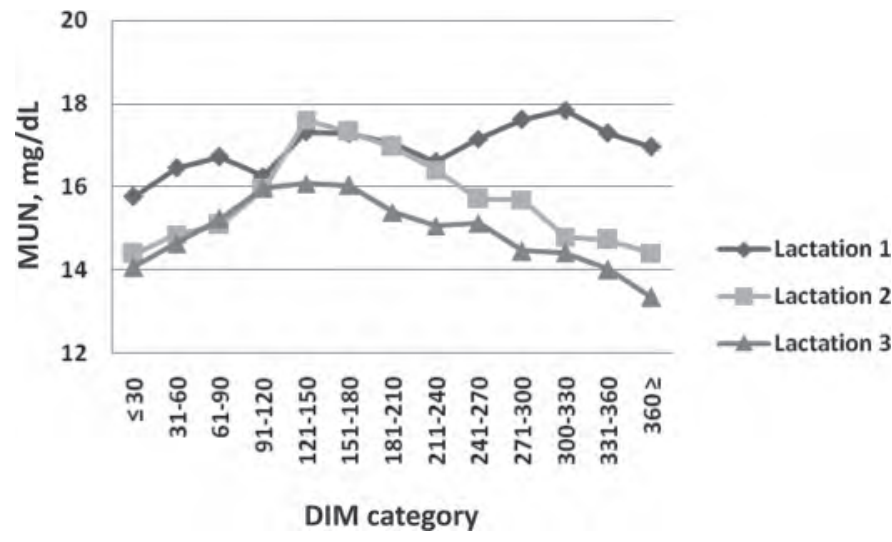

Figure 2. Least squares means of MUN concentration by lactation group and DIM for Iranian Holstein cows.

higher urea concentrations at peak lactation than in later lactation.

Jonker et al. (1999) modeled expected MUN concentrations for an entire lactation and showed that MUN concentrations resembled a lactation curve. In our study, however, MUN concentration reached a maximum at the fifth month of lactation, but milk production reached a maximum at the third month. In later lactation, as milk production declined, the protein requirement decreased, and we suggest that MUN should also decline. We observed that as milk declined, some of the herd MUN concentrations did not decline at the same rate (Figure 1). This suggests the possibility that for those herds, protein may have been overfed in late lactation or the ration contained a different amount of RDP than earlier in lactation. Godden et al. (2001a) and, to a lesser extent, Carlsson et al. (1995) showed a

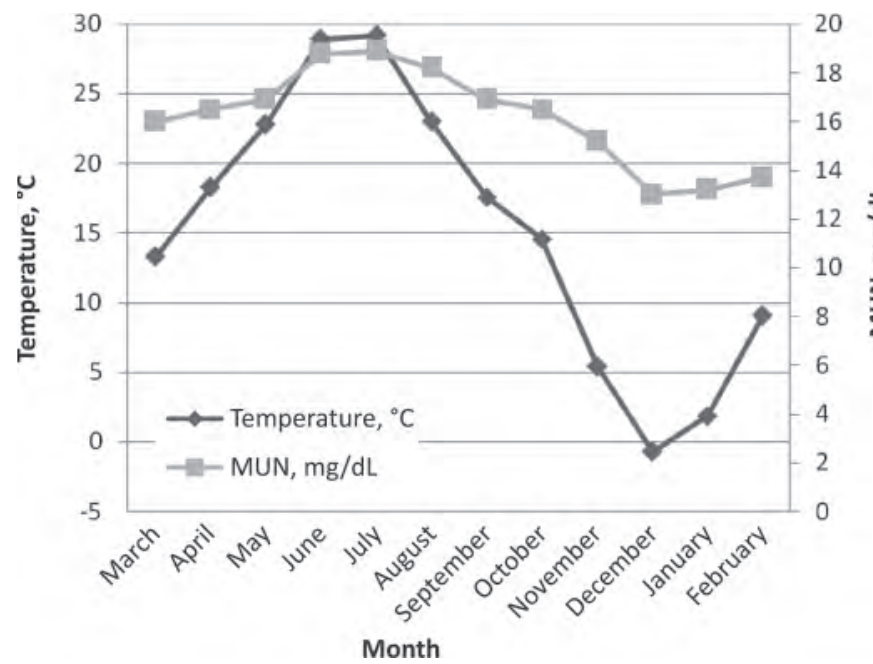

Figure 3. Influence of environmental temperature, by month of the year, on MUN concentration $(\mathrm{mg} / \mathrm{dL})$.
Table 5. Milk urea $\mathrm{N}$ concentration $(\mathrm{mg} / \mathrm{dL})$ by season and month of year for Iranian Holstein cows

\begin{tabular}{lcll}
\hline $\begin{array}{l}\text { Season } \\
\text { and month }\end{array}$ & $\begin{array}{c}\text { Environmental } \\
\text { temperature, }{ }^{\circ} \mathrm{C}\end{array}$ & $\begin{array}{l}\text { MUN, } \\
\mathrm{mg} / \mathrm{dL}\end{array}$ & $\mathrm{SE}$ \\
\hline Spring & 18.13 & $16.47^{\mathrm{b}}$ & 0.10 \\
March & 13.3 & 16.0 & 0.18 \\
April & 18.3 & 16.5 & 0.20 \\
May & 22.8 & 16.9 & 0.21 \\
Summer & 27.03 & $18.64^{\mathrm{a}}$ & 0.14 \\
June & 28.9 & 18.8 & 0.26 \\
July & 29.2 & 18.9 & 0.23 \\
August & 23.0 & 18.2 & 0.22 \\
Autumn & 12.53 & $16.22^{\mathrm{b}}$ & 0.12 \\
September & 17.6 & 16.9 & 0.23 \\
October & 14.6 & 16.5 & 0.22 \\
November & 5.4 & 15.2 & 0.21 \\
Winter & 3.43 & $13.33^{\mathrm{c}}$ & 0.11 \\
December & -0.7 & 13.0 & 0.20 \\
January & 1.9 & 13.2 & 0.22 \\
February & 9.1 & 13.7 & 0.26 \\
\hline
\end{tabular}

${ }^{a-c}$ Least squares means within the same column with different superscripts differ $(P<0.05)$.

positive relationship between milk yield and MUN. In addition, we saw the same relationship in our data. One ambiguous point in the data from the present study and in several other longitudinal survey studies (Carlsson et al., 1995; Godden et al., 2001b; Johnson and Young, 2003; Hojman et al., 2004; Wattiaux et al., 2005) is the lack of individual cow DMI and $\mathrm{N}$ intake data. These studies without DMI data cannot truly differentiate the cause and extent of MUN changes resulting from $\mathrm{N}$ and RDP intake, month, temperature, or stage of lactation.

\section{Associations Between MUN and Parity}

Changes in ration nutrient composition or feeding program that occur among parity groups and different stages of lactation could contribute to the variation observed in MUN. Physiological or behavioral differences may also be present that could affect MUN. Similar to our results, Jílek et al. (2006) reported higher MUN concentrations in cows in their first and second lactations $(5.63$ and $5.62 \mathrm{mmol} / \mathrm{L})$ than for groups in their third and fourth lactations $(5.47 \mathrm{mmol} / \mathrm{L})$. In addition, Johnson and Young (2003) recorded the highest MUN concentration in cows in the first lactation. Inversely, Carlsson et al. (1995) and Godden et al. (2001b) reported the lowest MUN concentrations in cows in the first lactation. However, these authors compared only cows in the first lactation with older ones (2 and more calving). In the current study, MUN concentration fluctuated during the year compared with the second and third lactations. However, the rate of decline in MUN from mid to late lactation was similar in animals in parity 2 or greater (Figure 2). 


\section{Associations Between MUN Categories and Production Variables}

Arunvipas et al. (2003) reported that the correlations of MUN with protein percentage and fat percentage were -0.212 and -0.117 , respectively. Broderick and Clayton (1997) also reported a negative relationship between MUN and milk fat percentage. Jonker et al. (1998) predicted that a change in milk fat of \pm 0.5 percentage units would change the estimated mean lactation MUN concentration by approximately \pm 1.70 $\mathrm{mg} / \mathrm{dL}$. The relationship between milk fat and MUN may be an indirect result of nutritional variables or a direct negative effect of milk fat on MUN (Carlsson and Bergstrom, 1994).

Because of the inverse relationship between MUN and milk protein percentage, lower MUN may be associated with a greater use of dietary $\mathrm{CP}$, leading to improved $\mathrm{N}$ utilization efficiency. Other reports have shown either no relationship between milk protein percentage and MUN (Broderick and Clayton, 1997; multiple regression model) or a negative, nonlinear association (Godden et al., 2001a).

This study observed a negative relationship between MUN and SNF percentage and between MUN concentration and TS percentage. These negative correlations may result from the negative correlation between milk protein percentage and milk fat percentage. However, we could not find other studies in which these parameters were investigated.

\section{Association Between MUN and Combinations of Milk Yield and Milk Protein Percentage Categories}

As reported by Nelson (1996), herd-level groupings of low, average, and high milk protein percentages in combination with 3 levels of MUN $(<12,12$ to 16 , and $>16$ $\mathrm{mg} / \mathrm{dL}$ ) may give an indication of an imbalance of protein and energy in the ration. He suggested that when milk protein was 3.0 to $3.2 \%$ and MUN concentration was 12 to $16 \mathrm{mg} / \mathrm{dL}$, protein degradability fractions and net energy were most likely balanced. In this study (Table 4), cow-level mean MUN (meant to simulate a herd-level mean) for each category of milk protein percentage and milk yield was within this range for Holsteins. An exception was that when milk production was very high ( 54.51 to $63.6 \mathrm{~kg} / \mathrm{d})$, MUN concentrations were higher.

\section{Associations Between MUN and Season (or Month)}

Iranian dairy cows are kept indoors through the year and fed a TMR of a relatively constant composition that generally does not include fresh-cut grass. Therefore, the seasonal influence on MUN concentration appears to be a direct one. Carlsson et al. (1995) reported that the changes in concentrations of urea in milk were much more regular throughout the lactation when the cows were housed than when they were on grass. These authors suggested that it was probably because any changes in the nutritional content of the cow's diet were more regular and controlled during the housing period.

In agreement with our results, Hojman et al. (2004) reported the lowest MUN level in November $(11.8 \mathrm{mg} /$ $\mathrm{dL})$, and it reached a maximum in June $(18.1 \mathrm{mg} /$ dL). In addition, Ferguson et al. (1997), Godden et al. (2001b), and Wattiaux et al. (2005) reported higher MUN concentrations during the summer months. They reported that total protein and true protein (mostly casein) in milk were lower during the summer months, whereas NPN, mostly urea, increased. Ferguson et al. (1997) reported that MUN varied by season as follows $(\mathrm{mmol} / \mathrm{L})$ : winter, $5.00 \pm 0.071$; spring, $5.35 \pm 0.075$; summer, $5.83 \pm 0.086$; and fall, $5.07 \pm 0.093$.

Table 6 shows mean ambient high and low temperatures by month at a central weather station site in Iran for the months in which the study occurred. In this study, MUN concentration was positively correlated with the monthly temperature mean (Figure 3 and Table 5). In addition, Hassan and Roussel (1975) reported that blood NPN content was positively correlated with rectal temperature, which is consistent with the reduced efficiency of energy use for excessive N (Tyrrell et al., 1970). Thus, the energy necessary to form urea from excess protein decreases as environmental heat increases. This decreases the proportion of $\mathrm{NE}_{\mathrm{L}}$ in $\mathrm{ME}$, and the energy lost in excreted urinary $\mathrm{N}$ from excess protein decreases the proportion of ME in $\mathrm{DE}$ (West, 1992).

The lower reproductive performance (such as conception rate) in Iranian Holstein cows during summer may be caused by a higher MUN concentration during this season. Larson et al. (1997) found that nonpregnant cows with low progesterone after breeding were often associated with high MUN. Butler et al. (1996) suggested that high MUN may be associated with a decrease in uterine $\mathrm{pH}$, which could make the environment within the uterus unsuitable for early embryo development. Hojman et al. (2004) also reported a negative effect of MUN on conception rate at first service among cows within herds, but no such effects were found at the second and third services.

Intake of DM usually declines with hot weather (summer), and nutrient density of the diet must increase. Therefore, in hot weather Iranian farms tend to increase the dietary protein concentration above requirements, 
Table 6. Mean ambient high and low temperatures $\left({ }^{\circ} \mathrm{C}\right)$ by month at a central weather station site in Iran for the months when the study occurred

\begin{tabular}{lccc}
\hline & \multicolumn{3}{c}{ Temperature, ${ }^{\circ} \mathrm{C}$} \\
\cline { 2 - 4 } Month & Minimum & Maximum & Mean \\
\hline March & -4 & 27 & 13.3 \\
April & 2 & 26 & 18.3 \\
May & 7 & 34 & 22.8 \\
June & 11 & 39 & 28.9 \\
July & 17 & 42 & 29.2 \\
August & 11 & 39 & 23.0 \\
September & 12 & 37 & 17.6 \\
October & 5 & 32 & 14.6 \\
November & 2 & 20 & 5.4 \\
December & -5 & 19 & -0.7 \\
January & -7 & 17 & 1.9 \\
February & -6 & 20 & 9.1 \\
\hline
\end{tabular}

but an energetic cost is associated with feeding excess protein. Excess $\mathrm{N}$ above requirements reduces ME by $7.2 \mathrm{kcal} / \mathrm{g}$ of $\mathrm{N}$ (West, 2003).

\section{CONCLUSIONS}

The present study examined some of factors (lactation, DIM, milk components, season) that influence MUN levels by using field data from cows continually kept indoors and fed TMR. It has been recommended that MUN concentration be evaluated in association with parity, DIM, and month (or secondarily by season). These variables should be considered potential sources of misinterpretation in exploring the relationship between MUN and nutritional management or measures of performance. In the current study, MUN was higher in the first lactation, and it fluctuated during the year compared with the second and third lactations. Milk urea $\mathrm{N}$ increased slowly over the first 4 mo, peaked in the fifth month of lactation, and then decreased later in lactation. A positive relationship existed between MUN concentration and milk yield, whereas negative relationships were observed with milk protein and milk fat percentages. In addition, MUN concentration was higher at the onset of the hot season and may result in lower reproduction performance during summer. This study was a necessary step in validating the use of MUN measurements from Iranian dairy herds as a tool to assist dairy producers.

\section{REFERENCES}

Arunvipas, P., I. R. Dohoo, J. A. VanLeeuwen, and G. P. Keefe. 2003. The effect of non-nutritional factors on milk urea nitrogen levels in dairy cows in Prince Edward Island, Canada. Prev. Vet. Med. 59:83-93.

Baker, L. D., and J. D. Ferguson. 1993. Milk urea nitrogen as a metabolic indicator of protein feeding efficiency on dairy farms. Pages
165-166 in Proc. 26th Annu. Convention Am. Assoc. Bovine Practitioners, Albuquerque, NM.

Baker, L. D., J. D. Ferguson, and W. Chalupa. 1995. Reponses in urea and true protein to different feeding schemes for dairy cows. J. Dairy Sci. 78:2424-2434.

Blanchard, T., J. Ferguson, L. Love, T. Takeda, B. Henderson, J. Hasler, and W. Chalupa. 1990. Effect of dietary crude-protein type on fertilization and embryo quality in dairy cattle. Am. J. Vet. Res. 51:905-908.

Bonnett, B. N. 1990. Interpretation of diagnostic tests: Skills for practice and research. Pages 10-22 in Proc. Annu. Meet. Soc. Theriogenol., Toronto, Ontario, Canada. Soc. Theriogenol., Montgomery, AL.

Broderick, G. A., and M. K. Clayton. 1997. A statistical evaluation of animal and nutritional factors influencing concentrations of milk urea nitrogen. J. Dairy Sci. 80:2964-2971.

Bruckental, I., J. D. Oldham, and J. D. Sutton. 1980. Glucose and urea kinetics in early lactation. Br. J. Nutr. 44:33-45.

Butler, W. R., J. J. Calaman, and S. W. Beam. 1996. Plasma and milk urea nitrogen in relation to pregnancy rate in lactating dairy cattle. J. Anim. Sci. 74:858-865.

Carlsson, J., and D. J. Bergstrom. 1994. The diurnal variation of urea in cow's milk and how milk fat content, storage and preservation affects analysis by a flow injection technique. Acta Vet. Scand. 35:67-77.

Carlsson, J., J. Bergstrom, and B. Pehrson. 1995. Variations with breed, age, season, yield, stage of lactation, and herd in the concentration of urea in bulk milk and individual cow's milk. Acta Vet. Scand. 36:245-254.

Eicher, R., E. Bouchard, and M. Bigras-Poulin. 1999. Factors affecting milk urea nitrogen and protein concentrations in Quebec dairy cows. Prev. Vet. Med. 39:53-63.

Ferguson, J. D., T. Blanchard, D. T. Galligan, D. C. Hoshall, and W. Chalupa. 1988. Infertility in dairy cattle fed a high percentage of protein degradable in the rumen. J. Am. Vet. Med. Assoc. 192:659-662.

Ferguson, J. D., N. Thomsen, D. Slesser, and D. Burris. 1997. Pennsylvania DHIA milk urea testing. J. Dairy Sci. 80(Suppl. 1):161. (Abstr.)

Godden, S. M., K. D. Lissemore, D. F. Kelton, K. E. Leslie, J. S. Walton, and J. H. Lumsden. 2001a. Factors associated with milk urea concentrations in Ontario dairy cows. J. Dairy Sci. 84:107-114.

Godden, S. M., K. D. Lissemore, D. F. Kelton, K. E. Leslie, J. S. Walton, and J. H. Lumsden. 2001b. Relationships between milk urea concentration and nutritional management, production, and economic variables in Ontario dairy herd. J. Dairy Sci. 84:11281139.

Gustafsson, A. H., and D. L. Palmquist. 1993. Diurnal variation of rumen ammonia, serum urea, and milk urea in dairy cows at high and low yields. J. Dairy Sci. 76:475-484.

Hassan, A., and J. D. Roussel. 1975. Effect of protein concentration in the diet on blood composition and productivity of lactating Holstein cows under thermal stress. J. Agric. Sci. (Camb.) 85:409415.

Hof, G., M. D. Vervoorn, P. L. Lenaers, and S. Tamminga. 1997. Milk urea nitrogen as a tool to monitor the protein nutrition of dairy cows. J. Dairy Sci. 80:3333-3340.

Hojman, D., O. Kroll, G. Adin, M. Gips, B. Hanochi, and E. Ezra. 2004. Relationships between milk urea and production, nutrition, and fertility traits in Israeli dairy herds. J. Dairy Sci. 87:10011011.

Jílek, F., D. Řehák, J. Volek, M. Štípková, E. Němcová, M. Fiedlerová, R. Rajmon, and D. Švestková. 2006. Effect of herd, parity, stage of lactation and milk yield on urea concentration in milk. Czech J. Anim. Sci. 51:510-517.

Johnson, R. G., and A. J. Young. 2003. The association between milk urea nitrogen and DHI production variables in western commercial dairy herds. J. Dairy Sci. 86:3008-3015.

Jonker, J. S., R. A. Kohn, and R. A. Erdman. 1998. Using milk urea nitrogen to predict nitrogen excretion and utilization efficiency in lactating dairy cattle. J. Dairy Sci. 81:2681-2692. 
Jonker, J. S., R. A. Kohn, and R. A. Erdman. 1999. Milk urea nitrogen target concentrations for lactating dairy cows fed according to National Research Council recommendations. J. Dairy Sci. 82:1261-1273.

Jordan, E. R., and L. V. Swanson. 1979. Effect of crude protein on reproduction efficiency, serum total protein and albumin in the high producing dairy cow. J. Dairy Sci. 62:58-63.

Kaim, M., Y. Folman, H. Neumark, and W. Kaufmann. 1983. The effect of protein intake and lactation number on post-partum body weight loss and reproductive performance of dairy cows. Anim. Prod. 37:229-235.

Kauffman, A. J., and N. R. St-Pierre. 2001. The relationship of milk urea nitrogen to urine nitrogen excretion in Holstein and Jersey cows. J. Dairy Sci. 84:2284-2294.

Kohn, R. A., K. F. Kalscheur, and E. Russek-Cohen. 2002. Evaluation of models to estimate urinary nitrogen and expected milk urea nitrogen. J. Dairy Sci. 85:227-233.

Larson, S. F., W. R. Butler, and W. B. Currie. 1997. Reduced fertility associated with low progesterone postbreeding and increased milk urea nitrogen in lactating cows. J. Dairy Sci. 80:1288-1295.

Miettinen, P. V., and R. O. Juvonen. 1990. Diurnal variation of serum and milk urea levels in dairy cows. Acta Agric. Scand. 40:289-296.

Nelson, A. 1996. Practical applications of MUN analyses. Bovine Pract. 29:85-95.

Ng-Kwai-Hang, K. F., J. F. Hayes, J. E. Moxley, and H. G. Monardes. 1985. Percentages of protein and nonprotein nitrogen with varying fat and somatic cells in bovine milk. J. Dairy Sci. 68:1257-1262.
Rajala-Schultz, P. J., W. J. A. Saville, G. S. Frazer, and T. E. Wittum. 2001. Association between milk urea nitrogen and fertility in Ohio dairy cows. J. Dairy Sci. 84:482-489.

Sackett, D. L., R. B. Haynes, G. H. Guyatt, and P. Tugwell. 1991. Clinical Epidemiology. 2nd ed. Little, Brown and Company, Toronto, Ontario, Canada.

SAS Institute. 2004. SAS/STAT 9.1 User's Guide. SAS Inst. Inc., Cary, NC.

Swenson, M. J., and W. O. Reece. 1993. Water balance and excretion. Pages 573-604 in Dukes' Physiology of Domestic Animals. 11th ed. Cornell Univ. Press, Ithaca, NY.

Tyrrell, H. F., P. W. Moe, and W. P. Flatt. 1970. Influence of excess protein intake on energy metabolism of the dairy cow. Pages 69-71 in Fifth Symp. Energy Metab. Farm Anim. Eur. Assoc. Anim. Prod. Publ. 13. Juris, Zurich, Switzerland.

Wattiaux, M. A., E. V. Nordheim, and P. Crump. 2005. Statistical evaluation of factors and interactions affecting Dairy Herd Improvement milk urea nitrogen in commercial Midwest dairy herds. J. Dairy Sci. 88:3020-3035.

West, J. W. 1992. Nutritional strategies for managing the heat-stressed dairy cow. J. Dairy Sci. 82(Suppl. 2):21-35.

West, J. W. 2003. Effects of heat-stress on production in dairy cattle. J. Dairy Sci. 86:2131-2144.

Wood, P. D. P. 1979. A simple model of lactation curves for milk yield, food requirement and body weight. Anim. Prod. 28:55-63. 